\title{
Possibilities and Specifics of Arctic Mineral Resources Development
}

\author{
Viktor I. Bragin a* \\ and Margarita J. Kharitonova ${ }^{\mathbf{b}}$ \\ ${ }^{a}$ Siberian Federal University \\ 79 Svobodny, Krasnoyarsk, 660041, Russia \\ ${ }^{b}$ Institute of Chemistry and Chemical Technology \\ SB RASFRC "Krasnoyarsk Science Center SB RAS" \\ 50/24 Akademgorodok, Krasnoyarsk, 660036, Russia
}

Received 28.04.2016, received in revised form 31.05.2016, accepted 20.09.2016

The paper presents the approach to the evaluation of the possibilities for the mineral resources deposits development in the Arctic territories of Siberia and, in particular, in the Krasnoyarsk Territory. It is shown that taking into account long-term tendencies of the economy development, the nearest 20 years of extensive development of mineral resources of the Arctic regions will not exert positive influence on the economy. The importance of the effective use of mineral resources and creation of management mechanism promoting the system organisation of this process is specified.

Keywords: mineral resources, mining operations efficiency, economic long waves, rationing, management.

This paper was prepared with the financial support from the Russian Humanitarian Science Foundation (RHSF) and the Krasnoyarsk Krai Science Foundation "Development of long-term scenarios and organizational-economic mechanisms of development of the Arctic zone of Krasnoyarsk Krai, and assessment of their influence on the socioeconomic state and dynamics of Krasnoyarsk Krai" (project no. 16-12-24007).

DOI: 10.17516/1997-1370-2016-9-10-2374-2382.

Research area: economics.

\section{Introduction}

Economic development of the new territories in the provinces with predominantly resourcebased specialization is an important component of economic recovery and growth stimulation. In Siberia, there are still large territories virtually undeveloped even by raw materials corporations. There is quite a general idea about the potential of these territories, not always sufficient for business to make conscious decision about expansion. Under these conditions a significant role in the development vector formation belongs to the state.

In central Siberia, in the Krasnoyarsk Territory the mountainous areas of the south, but also and above all, the Arctic, belong to such

(c) Siberian Federal University. All rights reserved

* Corresponding author E-mail address: vic.bragin@gmail.com 
poorly developed and studied areas. The need in attraction of the Arctic territories' resources demonstrated recently is determined by both the natural course of economic development and political circumstances, as well as the crises manifestations of the recent years. The question of how and in what way it is reasonable to adjust the approaches to the territory development under conditions of the today's changed circumstances is of interest. Below, the considerations on the issue relating to the technological, regulatory and organizational aspects of the deposits of solid minerals' development in northern areas of the Krasnoyarsk Territory are given.

\section{Approach statement}

Large mineral deposits development takes significant amount of time: the duration of the venue exploration, design and construction of an enterprise can take 10-15 years. Even greater time intervals occur in the course of the resource-based provinces development. During this time, raw materials markets environment can change, sometimes dramatically, with the complete change of priorities. Technological picture of the raw materials complex changes: modern, at the time of design, ore processing technology can become obsolete. Under these conditions, the ordinary development planning methods are not sufficiently presentable, and assessments that take into account longterm trends in economy and technology gain importance. Without replacing the conventional design technologies, these methods make it possible to identify "long-wave" component in the task.

An approach based on the concept of long waves by Kondratiev and subsequently developed by J. Schumpeter (Schumpeter, 1982) can be considered as a recognized method for longterm assessment. Later, on this basis, S. Glazyev developed the concept of technological modes
(Glazyev, 1989). The duration of the long wave, according to various assessments, is 40-60 years. The beginning of the wave is usually referred to the beginning of the upward part of the wave. It is convenient to separate the wave into four phases: expansion, boom, recession and depression. Each phase has indicative features concerning business and government strategies. Currently statistical data is collected in relation to five successive waves. In assessing the duration, as well as the moments of the beginning and the end of each wave, there are significant differences determined by the differences in the assessment procedure. This circumstance substantially reduces the forecasting importance of the method, however, it seems to be suitable for the long-term tendencies assessment at the semiquantitative, or at least qualitative level.

For the long-term assessment of the resource-based regions development, this model is convenient as it clearly distinguishes favorable, or, conversely, unfavorable phases for the resource-based economy, at that, giving an opportunity to make well-founded forecasts about the tendencies of technological development and appropriate organizational approaches. It is known that the phases of boom or, conversely, depression are the most favorable for the resource-based economy. Shoulder-season phases - expansion and recession are, on the contrary, not favorable for the extractive industries, as the relative value of raw materials, as compared to the consumer goods in these periods decreases. Technological development of the wave phases is uneven, as well. There are two points in largescale innovations: in the phase of expansion and in the phase of recession. At that, the first one - in the phase of expansion-starts the next long wave, ensuring growth, and the second one - in the phase of recession - provides optimization, costs reduction, increased efficiency and prepares the economy for winter. 
The question of the length of the current fifth long wave is debatable. Depending on the answer to it, conclusions and forecasts vary. There is a point of view, according to which the long wave duration decreases with every cycle, which is, in particular, determined by the development of economic ties and the growth of information processing speed. The last assessment concerning this point of view involves the fact that the fifth wave duration is less than 40 years and, thus, currently, the world economy is facing the phase of depression, and in 2 or 3 years the next phase of the next sixth long wave will begin. The next point of view identifies the current time as the early phase of depression, which will last for about 10 more years. And, finally, the traditional approach to defining the wave duration (50-55 years) leads to the consideration of the present moment as the beginning of the phase of recession.

Further in the paper, the author will follow the traditional view to the long wave duration. Thus, the approximate boundaries of the nearest phases are the following:

- recession (V wave):

$2014-2027$

- depression (V wave):

$2027-2040$

- expansion (VI wave)

$2040-2052$

Further in the article the possibilities and prospects of the raw material complex of the Arctic region of the Krasnoyarsk Territory will be considered in this context.

\section{Discussion of the Situation within the Framework of the Accepted Approach}

Recognition of the fact the world economy is entering the cyclic recession eventually involves the conclusion that the usual expansion in the Arctic territory currently will not bring benefits to national and, particularly, regional economy, but on the contrary, will be accompanied by freezing of sufficient amount of funds in inefficient capital stocks. The analysis should take into account at least the following factors:

- Poor conditions of the raw material markets at the current phase of recession and reduced consumption of raw materials in the future phase of depression

- The time lag of 10-15 years from venue exploration to starting the enterprise

- Intensive technological innovations in the phase of regression

- Competition for investments under conditions of significantly different technological level of production

- Low level of geological exploration and economic development of the region

The combined effect of these factors complicates the development of the resourcebased production in the Arctic. In the nearest 1015 years the market conditions will be unfavorable for investments into geological and mining growth-oriented business. At the end of recession and economy stabilization at the low level, the conditions will be more favorable, but the total raw materials consumption will be reduced, thus, the input of production capacities will be directed mainly at the mined-out reserves compensation. During the phase of recession a significant change in the technological image of the raw material shop will take place, and, as a result, designed according to the existing standards and built at this time enterprises from the very beginning will be in relatively unfavorable conditions. The original cause of this situation lies in the fact that extension is inappropriate in the phase of recession; it is the time for optimization and increase in efficiency.

For the figurative representation, it is possible to use an analogy from the previous long wave. The present situation roughly corresponds to, if we talk about the cycle phases, late $60 \mathrm{~s}$ of the $20^{\text {th }}$ century. Specialized press then was full of publications about the worsening 
prospects of mining business and the possible ways of optimization, both organizational and technological. If we take gold industry as a specific example, it was precisely at that time when "carbon in pulp" technology finishing was carried out, and in 1969 the United States Bureau of Mines recommended it for the new and reconstructed gold mining companies. This technology drastically reduced capital capacity and prime cost, in relation to the prevailing at that time kinds of sludge process. It was this new CIP-CIL process that quickly changed the technological image of the gold industry in the 70s. Later, with the coming of the phase of depression in the 70-80s, and a sharp increase in the price of gold in this connection, the technology provided growth in metal production. The result of these events was the radical change of the whole industry for 20-25 years. Gold production shifted from the countries with rich ores, especially the Republic of South Africa, to the countries with poor ores, but with the advanced technologies, and the total gold production increased by more than $50 \%$.

The current situation is similar to the aforementioned one, suggesting the similar effects. The prevailing tendency in the mining business organization and technology in the recent years took shape of a tendency for optimization under conditions of growth restrain. All big companies implement their complex optimization programmes. The areas of energy and resource saving became the priority areas of technological development. In particular, in the field of mineral raw materials preparation there is a complex international programme, aimed at reducing costs in the most energy-intensive stage of the technological chain by $30-40 \%$ in the next 10 years. Thus, the raw materials industry is preparing to survive autumn and successfully enter winter with minimum costs.

\section{Solution strategies}

In light of the above, the issue of the Siberian Arctic development acquires additional dimensions. In view of the above considerations, there are no reasons to believe that large-scale involvement of additional mineral resources to the economy will have a positive effect for the next 20-25 years. At the same time, the development of the Arctic can be viewed at the angle of implementing the policy of primary production efficiency increase. In this case, we can expect the lagged effect, which will be noticeably manifested in 10-15 years, upon the occurrence of the phase of depression and related improvement in raw materials conditions.

It is possible to consider three main components of this policy that will be conventionally called technology, organization and strategy.

\section{Technology}

Cyclical recession period is the time for innovations aimed at reducing costs and increasing efficiency. These innovations are based on technological approaches gained in the previous years. In the field of solid minerals technology, at the moment, there is a whole range of new products, rapidly gaining their share in the industry. The following ones should be emphasized in connection with the issue under consideration:

- Cost-effective and operational methods of mineral resources search and exploration

- Energy-saving production technologies of mineral resources extraction and processing

- Extraction technologies based on hydrofracturing

Regarding the North development, up-to-date technologies of search and exploration become crucial. Under conditions of large territories, access difficulty and unfavorable climate conditions typical to the northern territories, it 
is possible to achieve the necessary degree of exploration for the foreseeable future only with the use of the most advanced technologies. They include all sorts of remote sensing technologies, geochemical and geophysical prospecting technologies, etc.

Energy-saving technologies of mineral resources processing occupy a special place. It is estimated that about $5 \%$ of all electricity produced in the world is used only for the crushing and grinding of ores prior to enrichment. At present, rapid changes are taking place in this area, new grinding equipment is rapidly replacing the traditional mills. According to the forecasts, in 10 years the face of the industry will be completely changed. At Russian factories such equipment now is very rare; there is no domestic production of the equipment.

Another aspect of energy saving in the mineral raw materials processing is the socalled pre-concentration of ores. The point of this operation is to remove the largest possible parts of the rock in the form of lumps before grinding, the most energy-intensive processing operation. Pre-concentration is carried out by various methods, but radiometric sorting and separation is the most universal one. At present it is also rapidly developing area of technology that uses impulse developed in computer technologies for its growth. Pre-concentration by gravity methods after the raw materials preparation has also appeared in the technology of high pressure rollers - another high-tech project of the recent years.

Hydrofracturing technologies, more precisely the peculiarities of their spread, have demonstrated new features of the complex global market over the past two years. After the decline in oil prices, the number of companies engaged in exploration and production of shale oil and gas sharply fell down. At the same time, the people competent in new technologies of work in the interior have not disappeared, but apparently found new applications to their skills. Recently, publications about the works on the underground leaching of metals with the use of hydraulic fracturing technology have appeared in the industry journals. Taking into account the amount of companies working in accordance with the hydraulic fracturing technology that released for the recent time, we can expect a significant progress of physico-chemical methods of geotechnology in the next few years. Such methods of production are very promising for the northern regions.

The question of the methods for promoting innovation in the industry, including the abovementioned, is not easy. All the participants of the process understand the necessity to increase the production efficiency, but there is no motivation for the real actions. To obtain real results in the process of the Arctic development, changes in the system of subsurface use regulations that could create incentives for development are required.

\section{Organization}

Subsurface users' motivation to improve the primary production efficiency, generally speaking, is formed by the current market situation in which the enterprises that avoid optimization suffer losses. However, to define the expressed vector of development, the state is advisable to adopt additional stimulus measures. A strong solution may be setting a kind of efficiency standard by the regulator. Under current conditions of the developing recession, the change of subsurface use priority is justified: to reduce the growth rate of the developed reserves, simultaneously increasing the technological level of production. It can be implemented when changing the loss rationing system, under condition of transition from the individual to group standards.

The carried out analysis showed that the technological lag of the raw materials industry 
is determined not by the individual problems of separate enterprises or lack of attention from the state to the innovation processes, but the key approach to the mineral resources development and the established system of subsurface use management. Customized for each enterprise loss ratios, generated on the basis of the information on the field represented by the subsurface user are the formalized basis for the preservation of the existing technological level and corresponding motivation of mineral companies. The current practice limits the possibilities for the engineering and technology businesses development in the industry. Transition to the group losses standards is a possible way to solve the problem. Its implementation gives opportunity to motivate mineral companies towards the more rational use of resources and accelerated technological development, to stimulate engineering and technology business, to make mineral resources management more transparent and logical and, ultimately, successfully fulfill the basic requirements of the Subsoil Law.

The main features of the proposed system are the following:

1. The state defines generalized standards with regard to the use of mineral raw materials efficiency, which must be respected by all the subsurface users. The subsurface user's consent to follow the standard they are declared to is a necessary condition for granting the license for the subsurface area development.

2. The efficiency standards are set not individually for each deposit, but in the form of group standards for separate sectors, combining technologically similar deposits.

3. The standards are set based on the analysis of global experience in the development of similar fields, focusing on the best examples.

4. The state may alter the efficiency standards, with the aim to stimulate technological development (tightening standards) or to stimulate production (lower standard) for the industry as a whole.

5. Subsurface areas, which development would be insufficiently profitable for the subsurface users under conditions of the given regulations, are not licensed and remain in the undistributed fund.

\section{Strategy}

In the process of the new territories' raw material resources development, problems caused by the strategic grounds of subsurface users escalate. The first subsurface users in the new territory are usually lucky rent seekers, that "skim the cream" from the unmined rich deposits. Activities of the first subsurface users improve exploration of the territory and develop infrastructure, but, unfortunately, their productive activities are usually far from being effective. Therefore, under conditions of ordinary standard management of subsurface use, efficiency rise at the first stage of the territory development is not expected.

There is a convenient metaphor, developed in the evolutionary economics that uses the analogy between the biological communities and economic systems. Enterprises, including the mining ones, are divided into groups based on two parameters: in relation to the resources and the ability to compete (Bragin, 2010). The first group is "ruderals". These economic agents operate under conditions of excess resources, they are prone to expansion, a kind of pioneers, mastering an unoccupied market niche or segment. At that, they are very sensitive to external influences, and therefore, do not tolerate competition. Technologically they are prospectors, since their activity, in addition to the richest reserves mining, leads to an increase in the territory exploration and giving it understandable and attractive image for the enterprises of the second group - "competitor". When the excess 
resources run out, this particular subject replaces the ruderal. Since the ruderal is poorly adapted for the competition, it cannot withstand the pressure from the "competitor" that effectively uses resources, prone to large-scale activities, to retain its positions and is focused on long-term operation. And finally, the third group - "stresstolerators". These agents are able to work under conditions of the significant lack of resources and their low quality, under conditions that protect from the competition with rivals and, all the more, with the ruderals. Their function is to survive and adapt to the unfavorable conditions. These are enterprises that, as a rule, do not have profit or even loss-bearing ones, they spend all their income to pay off the costs.

Effective subsurface use management at the state level lies in stimulating constructive competitor's strategies and restricting the activity of the destructive policies bearers - ruderals and stress-tolerators (Peshkov, 2009). Stress-tolerators are not typical for the new territories; the main problem here is ruderals, predators. In the world practice, a set of tools to optimize the impact from the ruderals' actions was developed, in a typical form these are different kinds of arrangements for the differential rent withdrawal.

Mining rent management system creation and maintenance is the most important objective not only in terms of the industry efficiency increase, but also in the larger, systemic terms. The main mechanism of the resource-based economy institutions destruction is suppression of the competition mechanisms. It is in this case, the search for efficiency that stimulates innovation is replaced by rent seeking with all the negative ensuing consequences. Mining rents and ruderals management is a major problem in the efficient system of management construction.

To obtain objective data on the real rate of return from the raw materials projects, an approach, based on the statistical processing of the entire data set of the exploited mineral resource base and the statistical assessments construction may be useful. This approach allows getting the necessary objective information about the necessary production costs and expected returns of the project already at the stage of pre-assessment (Kharitonova, 2015). In the course of the new territories development it is advisable to establish and maintain a permanent monitoring system that allows to implement this method to determine the extent of the necessary rent withdrawal, or, conversely, subsurface use stimulation.

\section{Conclusions}

Consideration of the issue of the prospects for development of the mineral resources in the Arctic with the use of the long waves methodology has shown that under the present conditions the ordinary methods of expansion with the largescale expansion of mineral resources will not give the desired effect for the country and the region. For the Arctic development the ideology of production efficiency increase is more promising. To implement modern, already developing at the foreign enterprises, technologies in the new enterprises of the North, it is necessary to modify the system of subsurface use management in the newly developed areas, what would provide the desired motivation for the subsurface users.

\section{References}

Bragin, V.I. Normirovanie poter' poleznykh iskopaemykh pri pererabotke kak instrument aktivizatsii tekhnologicheskogo razvitiia [Processing Losses Regulation as Method of Technological Development Intensification], In Journal of Siberian Federal University, Humanities and Social Sciences, Krasnoyarsk, 2015, 5 (8), 180-189. 
Bragin, V.I. Pererabotka mineral'nogo syr'ia. Problemy innovatsionnogo razvitiia [Mineral Processing. Problems of Innovative Development], In Prirodnye resursy Krasnoyarskogo Kraia [Natural Resources of the Krasnoyarsk territory], 2010, 6, 36-40.

Glazyev, S.Y., Mikerin, G.I. Dlinnye volny NTP i sotsial'noekonomicheskoe razvitie [Long Waves of STP and Social and Economic Development]. M, Nauka, 1989.

Peshkov, A.A., Bragin, V.I. Struktura mineral'no-syr'evogo kompleksa, strategii nedropol'zovaniia i perspektivy rosta [Structure of Mineral Resources Sector, Subsurface Use Strategies and Growth Prospects], In Trudy nauchnogo simposiuma "Nedelia gorniaka 2009” [Proceedings of Scientific Symposium “The Week of Miner 2009”]. M., Sholokhov Moscow State University for the Humanities, 264-273.

Peshkov, A.A., Bragin, V.I., Mikhailov, A.G., Matsko, N.A. Geotekhnologicheskaia podgotovka mestorozhdenii poleznykh iskopaemykh [Geotechnological Preparation of Mineral Resources Deposits]. Moscow, Nauka, 2007, 286 p.

Kharitonova, M.Y., Matsko, N.A. Razvitie veroiatnostnoogo podkhoda k otsenke dostupnosti mestorozhdenii poleznykh iskopaemykh [Development of Probabilistic Approach to the Mineral Resources Deposits Availability Assessment], In Geologia i mineral'no-syr'evie resursy Sibiri [Geology and Mineral Resources of Siberia], 2015, 2 (22), 104-107.

Schumpeter, J. Teoria ekonomicheskogo razvitiia [The Theory of Economic Development]. M., Progress, 1982, 452.

\title{
Перспективы и особенности освоения
} минеральных ресурсов Арктики

\author{
В.И. Брагин \\ ${ }^{a}$ Сибирский федеральный университет \\ Россия, 660041, Красноярск, пр. Свободный, 79 \\ ${ }^{\sigma}$ Институт химии и химической технологии \\ СО РАНФИЦ \\ «Красноярский научный изентр СО РАН» \\ Россия, 660036, Красноярск, Академгородок 50/24
}

\begin{abstract}
В статье изложен подход к оценке перспектив освоения месторождений полезных ископаемых арктических территорий Сибири и, в частности, Красноярского края. Показано, что с учетом долговременных тендениий развития экономики ближайшие 20 лет масштабное освоение минеральных ресурсов Арктики не окажет позитивного влияния на экономику. Отмечена важность эффективного использования минеральных ресурсов и создания механизма управления, способствующего системной организации этого процесса.
\end{abstract}

Ключевые слова: минеральные ресурсы, эффективность добычи, длинные волны, нормирование, управление.

Исследование выполнено при финансовой поддержке РГНФ и краевого государственного автономного учреждения «Красноярский краевой фонд поддержки научной и научно-технической деятельности» в рамках научно-исследовательского проекта «Разработка долгосрочных сие- 
нариев и организационно-экономических механизмов развития Арктической зонь Красноярского края и оценка их влияния на социально-экономическое состояние и динамику Красноярского края» (проект № 16-12-24007).

Научная специальность: 08.00.00 - экономические науки. 